\title{
Evaluation of activity and combination strategies with the microtubule-targeting drug sagopilone in breast cancer
}

\section{cell lines}

\section{Julia Eschenbrenner ${ }^{1,2}$, Sebastian Winsel 1,3,4, Stefanie Hammer ${ }^{1}$, Anette Sommer ${ }^{5}$, Kevin Mittelstaedt ${ }^{1,3,6}$, Michael Drosch ${ }^{1,7}$, Ulrich Klar ${ }^{1}$, Christoph Sachse ${ }^{8}$, Michael Hannus ${ }^{8}$, Monika Seidel ${ }^{8}$, Bertram Weiss ${ }^{5}$, Claudia Merz ${ }^{5}$, Gerhard Siemeister ${ }^{1}$ and Jens Hoffmann ${ }^{1,9 *}$}

\author{
1 Global Drug Discovery, Therapeutic Research Group Oncology, Bayer Healthcare Pharmaceuticals, Berlin, Germany \\ 2 Institute for Biotechnology, Technical University Berlin, Berlin, Germany \\ ${ }^{3}$ Institute for Chemistry and Biochemistry, Free University Berlin, Berlin, Germany \\ ${ }^{4}$ Medical Biotechnology, VTT Technical Research Centre of Finland, Turku, Finland \\ ${ }^{5}$ Global Drug Discovery, Target Discovery, Bayer Healthcare Pharmaceuticals, Berlin, Germany \\ ${ }^{6}$ Department of Medicine, The University of Melbourne, Melbourne, VIC, Australia \\ 7 Center of Human Genetics, University of Bremen, Bremen, Germany \\ ${ }^{8}$ Cenix BioScience GmbH, Dresden, Germany \\ ${ }^{9}$ Experimentelle Pharmakologie und Onkologie Berlin-Buch GmbH, Berlin, Germany
}

\section{Edited by:}

Eric Solary, University Paris-Sud, France

\section{Reviewed by:}

Oliver Micheau, Institut National de la Santé et de la Recherche Médicale, France

Gavin McStay, Columbia University, USA

\section{*Correspondence:}

Jens Hoffmann, Experimentelle Pharmakologie and Onkologie Berlin-Buch GmbH, Robert Rössle-Str. 10, 13125 Berlin, Germany. e-mail:jens.hoffmann@ epo-berlin.com

\begin{abstract}
Sagopilone, a fully synthetic epothilone, is a microtubule-stabilizing agent optimized for high in vitro and in vivo activity against a broad range of tumor models, including those resistant to paclitaxel and other systemic treatments. Sagopilone development is accompanied by translational research studies to evaluate the molecular mode of action, to recognize mechanisms leading to resistance, to identify predictive response biomarkers, and to establish a rationale for combination with different therapies. Here, we profiled sagopilone activity in breast cancer cell lines. To analyze the mechanisms of mitotic arrest and apoptosis and to identify additional targets and biomarkers, an siRNA-based RNAi drug modifier screen interrogating 300 genes was performed in four cancer cell lines. Defects of the spindle assembly checkpoint (SAC) were identified to cause resistance against sagopilone-induced mitotic arrest and apoptosis. Potential biomarkers for resistance could therefore be functional defects like polymorphisms or mutations in the SAC, particularly in the central SAC kinase BUB1B. Moreover, chromosomal heterogeneity and polyploidy are also potential biomarkers of sagopilone resistance since they imply an increased tolerance for aberrant mitosis. RNAi screening further demonstrated that the sagopilone-induced mitotic arrest can be enhanced by concomitant inhibition of mitotic kinesins, thus suggesting a potential combination therapy of sagopilone with a KIF2C (MCAK) kinesin inhibitor. However, the combination of sagopilone and inhibition of the prophase kinesin KIF11 (EG5) is antagonistic, indicating that the kinesin inhibitor has to be highly specific to bring about the required therapeutic benefit.
\end{abstract}

Keywords: translational cancer research, breast cancer, microtubule-stabilizing agent, epothilone, sagopilone, RNA $i$ screening, spindle assembly checkpoint, mitotic kinesins

\section{INTRODUCTION}

Breast cancer is the most prevalent cancer worldwide, with 2002 global statistics reporting $>1$ million new cases diagnosed annually and $>400,000$ deaths (Parkin et al., 2005). The treatment of breast cancer is complicated by the diversity of breast tumor types resulting from variation in their associated transcriptional programs (Perou et al., 2000). Molecular characterization of breast cancer has led to the determination of a number of different subtypes and gene expression signatures that correlate with clinical factors such as prognosis, tumor recurrence, and survival (Sørlie et al., 2001; Wang et al., 2005). As a consequence, there has been a shift toward more tailored therapies against specific disease types in the clinic (Hatake et al., 2007), for example, the addition of trastuzumab/lapatinib to chemotherapy for
HER2-positive tumors. This combination approach is changing the standards of care in breast cancer (National Comprehensive Cancer Network, 2008). Optimal treatment for patients suffering from this heterogeneous disease will increasingly rely on gene expression/biomarker analysis to determine the most appropriate patient population for each treatment and the best therapy combinations for each patient, balancing response, and tolerability while avoiding resistance. This remains a major challenge (Gonzalez-Angulo et al., 2007) and it is therefore important to combine the development of new therapeutic agents for patients with breast cancer with research into optimal patient populations and tailored treatment combinations at the earliest opportunity.

Microtubule-stabilizing taxanes (for review see Jordan et al., 1993; Wahl et al., 1996; Jordan and Wilson, 2004; Risinger et al., 
2009) are major contributors to successful breast cancer treatment regimens when given as combination therapy. However, resistance may develop because of mechanisms that include PgP efflux transporter systems (Horwitz et al., 1993). Sagopilone, the first fully synthetic epothilone in clinical development, was optimized to overcome the limitations associated with conventional tubulinbinding agents, by combining high potency with a balanced safety profile (Klar et al., 2006). It has demonstrated high in vitro and in vivo activity against a range of tumor models compared with paclitaxel and other commonly used chemotherapy agents (Klar et al., 2006) and, given its specific and superior tubulin targeting activity (Hoffmann et al., 2008), sagopilone may have a potential in the treatment of breast cancer.

Sagopilone activity and its molecular mode of action have already been studied thoroughly in several other types of cancer. Similar to other microtubule-stabilizing agents, sagopilone interferes with microtubule dynamics with low concentrations leading to abnormal mitosis and higher concentrations resulting in mitotic arrest (Torres and Horwitz, 1998; Chen et al., 2003; Winsel et al., 2011). Following mitotic arrest, apoptosis is induced via loss of mitochondrial membrane potential resulting in the activation of the apical caspases 3 and 9 in HCT116 colon cancer cells (Hoffmann et al., 2008). Here, we present data describing sagopilone's mechanisms of proliferation inhibition in breast cancer cells.

To deepen our understanding of the molecular mode of action and possible resistance mechanisms we identified genes whose activity putatively modify sagopilone activity. Our knowledgebased selection contained genes previously seen to be regulated by sagopilone or paclitaxel (Hammer et al., 2010; Winsel et al., 2011), genes previously described as predictors for paclitaxel and/or docetaxel sensitivity (Bergstralh and Ting, 2006; Potti et al., 2006; Swanton et al., 2007), genes reported in chromosomal instability (CIN) signatures (Kim et al., 2004), and genes with the following gene ontology annotations: drug transport, drug metabolism, tubulin, spindle assembly checkpoint (SAC), cell cycle control, or microtubule-associated proteins (http://www.ebi.ac.uk/GOA). We employed the RNAi screening technology (Swanton et al., 2007; Whitehurst et al., 2007) to determine the modifying effects of reduced gene expression on sagopilone activity in breast cancer cell lines.

Breast cells may be driven into malignant proliferation by many different pathways, such as over-expressed/constitutively active growth or transcription factors, apoptotic or survival pathway defects or abnormalities in SAC control (Carvalho et al., 2003; Sudo et al., 2004; Huang et al., 2005; Groth-Pedersen et al., 2007). The aim of the studies presented in this paper, was to examine the activity of sagopilone in vitro in a broad range of breast tumor models. An RNAi drug modifier screen was employed to investigate possible resistance mechanisms and predictors of response, and potentially provide a rationale for combining sagopilone with other therapies to eventually deliver tailored treatment.

\section{RESULTS}

\section{IN VITRO PROFILE OF SAGOPILONE IN BREAST CANCER CELL LINES}

The growth inhibitory effect of sagopilone was compared with ixabepilone and paclitaxel in 20 breast cancer cell lines in a proliferation assay (Figure 1A). Sagopilone inhibited proliferation more strongly than ixabepilone or paclitaxel in all breast tumor cell lines tested, with $\mathrm{IC}_{50}$ values ranging from 0.2 to $1.8 \mathrm{nM}$. Moreover, sagopilone was effective at sub-nanomolar concentrations $(\leq 1 \mathrm{nM})$ in the majority of these cell lines (13 of 20$)$. The activity of sagopilone was examined in both estrogen receptor $\alpha$ $(\mathrm{ER} \alpha)$-positive and $\mathrm{ER} \alpha$-negative breast cancer cell lines. Sagopilone strongly inhibited the growth of six ER $\alpha$-positive (mean $\mathrm{IC}_{50}$ $1.2 \pm 0.9 \mathrm{nM}$ ) and the $\mathrm{ER} \alpha$-negative (mean $\mathrm{IC}_{50} 0.9 \pm 0.4 \mathrm{nM}$ ) breast cancer cell lines (Figure 1A). Previously, the uptake of sagopilone in A549 lung cancer cells was shown to be more rapid and effective than that of paclitaxel (Hoffmann et al., 2008). The anti-proliferative activity of sagopilone, ixabepilone, and paclitaxel were compared after different drug incubation times (Figure 1B). The $\mathrm{IC}_{50}$ values indicate that sagopilone elicits a stronger and more rapid anti-proliferative effect than paclitaxel after $1-72 \mathrm{~h}$ drug incubation. In addition, the minimal $\mathrm{IC}_{50}$ was reached for sagopilone after only $1 \mathrm{~h}$ incubation, while it took at least $7 \mathrm{~h}$ of drug incubation for ixabepilone and paclitaxel to reach their respective minimal $\mathrm{IC}_{50}$.

\section{SAGOPILONE INTERFERES WITH CYTOSKELETAL FUNCTIONS AND AFFECTS CELL CYCLE IN BREAST CANCER CELL LINES}

Vehicle-treated MDA-MB-231 breast cancer cells showed a normal microtubule spread in interphase cells and typical bipolar spindle with congressed chromosomes at the metaphase plate in mitotic cells (Figure 2). Treatment with $3 \mathrm{nM}$ sagopilone-induced multipolar spindles in mitotic cells while interphase cells were not affected. In contrast, MDA-MB-231 breast cancer cells incubated with $40 \mathrm{nM}$ sagopilone exhibited marked microtubule bundling in interphase cells, which led to an abnormal spindle organization in metaphase cells, with multiple spindle poles, several plates of congressed chromosomes, and an irregular chromosomal alignment.

Sagopilone-induced cell cycle arrest was quantified in MDAMB-231, T47D, MCF7, SKBR3, and MDA-MB-435s breast cancer cells (Figure 3) using fluorescence-activated cell sorter (FACS) analysis (see Materials and Methods for discussion of origin of MDA-MB-435s cells). Two different phenotypes were observed. Low concentrations of sagopilone $(<5 \mathrm{nM})$ induced aberrant cell division resulting in the formation of increasing numbers of aneuploid cells with reduced DNA content, but mitotic arrest was not induced. A second phenotype was observed at higher concentrations of sagopilone ( $\geq 10 \mathrm{nM}$ ), where the cell cycle progression was blocked in G2/M phase reaching a maximum after $18 \mathrm{~h}$ of incubation. The sagopilone concentration required to induce mitotic arrest varied between cell lines, but the maximal percentages of cells in mitotic arrest reached $70-80 \%$ for all five cell lines. Independently of the phenotype at high or low sagopilone concentrations, treatment with sagopilone resulted in the inhibition of cell proliferation.

\section{SAGOPILONE LEADS TO APOPTOSIS AND SENESCENCE}

The activity of caspase 3 and 7 was compared in ER $\alpha$-negative (MDA-MB-231, MDA-MB-435s, SKBR3) and the ER $\alpha$-positive (MCF7, T47D) breast cancer cells after $48 \mathrm{~h}$ incubation with sagopilone (Figure 4A). Caspase $3 / 7$ activity was detected at 


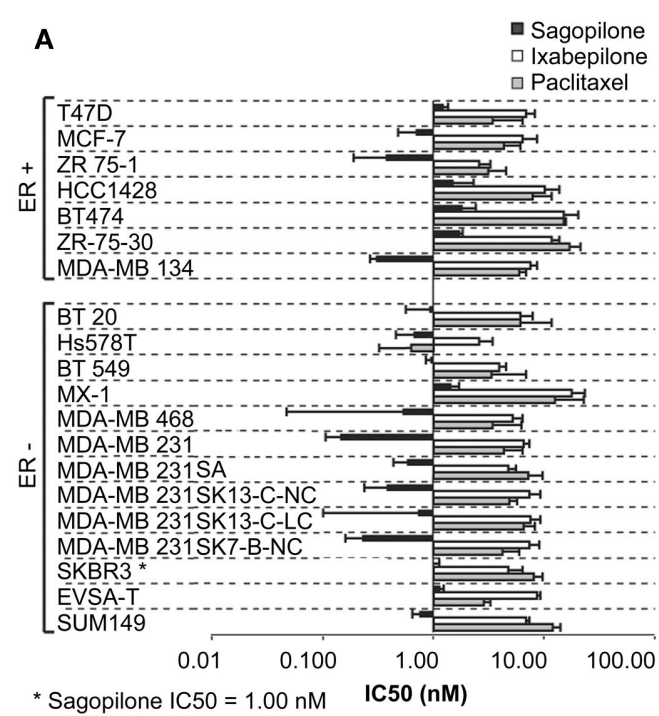

FIGURE 1 | Sagopilone inhibits proliferation in breast cancer cell lines irrespective of ER $\alpha$ status. (A) Inhibition of proliferation in 20 breast cance cell lines by sagopilone, ixabepilone, and paclitaxel after $72 \mathrm{~h}$. Cell lines were sorted according to their estrogen receptor $\alpha(E R \alpha)$ status. Mean $I C_{50}$ values

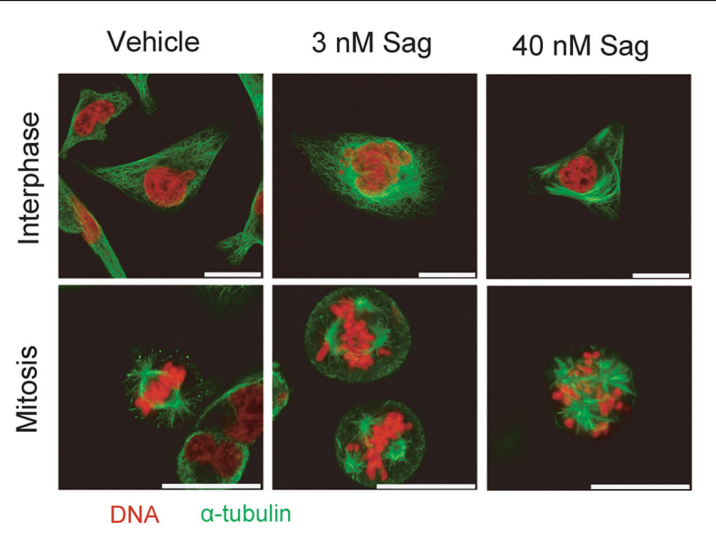

FIGURE 2 | Effect of sagopilone on tubulin cytoskeleton in MDA-MB-231 breast cancer cells. Immunofluorescence staining of $\alpha$-tubulin (green) and DNA (red) in MDA-MB-231 breast cancer cells after incubation for $20 \mathrm{~h}$ with either vehicle (ethanol), 3 or $40 \mathrm{nM}$ sagopilone (Sag). Scale bar $=20 \mu \mathrm{m}$. Images representative of more than five independent experiments.

low and high concentrations of sagopilone in all cell lines but not in the caspase 3-negative MCF7 cell line. After $72 \mathrm{~h}$ incubation, a concentration-dependent loss of cellular vitality was observed in MDA-MB-231, SKBR3, MCF7, and T47D breast cancer cells (Figure 4B). Among the remaining vital cells, loss of mitochondrial membrane potential was detected at low and high concentrations of sagopilone.

In order to analyze the colony forming potential of cells remaining vital in the presence of sagopilone, clonogenic assays were performed (Figure 5A). A 2-h incubation with $100 \mathrm{nM}$ sagopilone completely inhibited colony forming in T47D, SKBR3, and
B

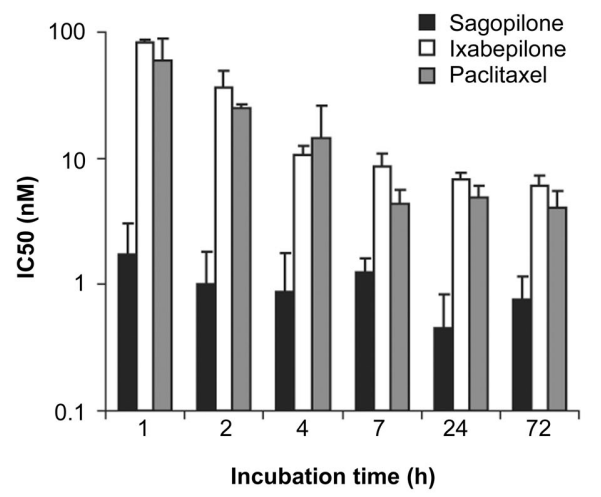

and SDs of triplicate experiments are shown. (B) Anti-proliferative effects of sagopilone, ixabepilone, and paclitaxel on MCF7 cells after incubation times ranging from 1 to $72 \mathrm{~h}$. Mean $I C_{50}$ values and SDs of triplicate experiments are shown.

A549 cancer cells, but only partially in MCF7 cancer cells. A 24-h treatment with $0.1 \mathrm{nM}$ sagopilone reduced colony formation significantly in all four cell lines tested. However, MCF7 breast cancer cells were the most resistant, forming even after $24 \mathrm{~h}$ treatment with $100 \mathrm{nM}$ sagopilone still $\sim 20 \%$ of the colonies in comparison to the vehicle-treated cells.

Though low-dose treatment (sagopilone concentration approximately equivalent to $\mathrm{IC}_{50}$, below $3 \mathrm{nM}$ ) reduced colony formation, cells remained vital for weeks (microscopic observation, images not shown). As induction of senescence might be one additional mechanism for the growth inhibitory effect of sagopilone at low concentrations - we investigated induction of senescence-associated $\beta$-galactosidase (Dimri et al., 1995) in sagopilone-treated cells. Cellular senescence was twofold increased in T47D cells at $1 \mathrm{nM}$ sagopilone (Figure 5B).

\section{RNAi DRUG MODIFIER SCREEN REVEALS SPINDLE ASSEMBLY CHECKPOINT PROTEINS AND MITOTIC KINESINS AS MODIFIERS OF SAGOPILONE ACTIVITY}

Regardless of breast cancer heterogeneity, sagopilone consistently inhibited tumor cell proliferation in vitro. In order to investigate the mechanisms behind the activity of sagopilone, the knockdown of 300 genes implicated in cell cycle control, apoptosis, $\mathrm{CIN}$, and taxane resistance was combined with sagopilone treatment in a high-throughput RNAi drug modifier screen in three breast cancer cell lines MCF7, T47D, and MDA-MB-435s and, for comparison, the A549 lung cancer cell line (see Materials and Methods for discussion of MDA-MB-435s origin). The screen was based on microscopic evaluation of DNA-stained nuclei. Preliminary experiments showed that after $24 \mathrm{~h}$ of sagopilone treatment the percentage of nuclei with condensed chromatin reflects sagopilone-induced mitotic arrest. In order to evaluate both sensitizing and suppressing effects of RNAi-mediated knockdown, two 
A
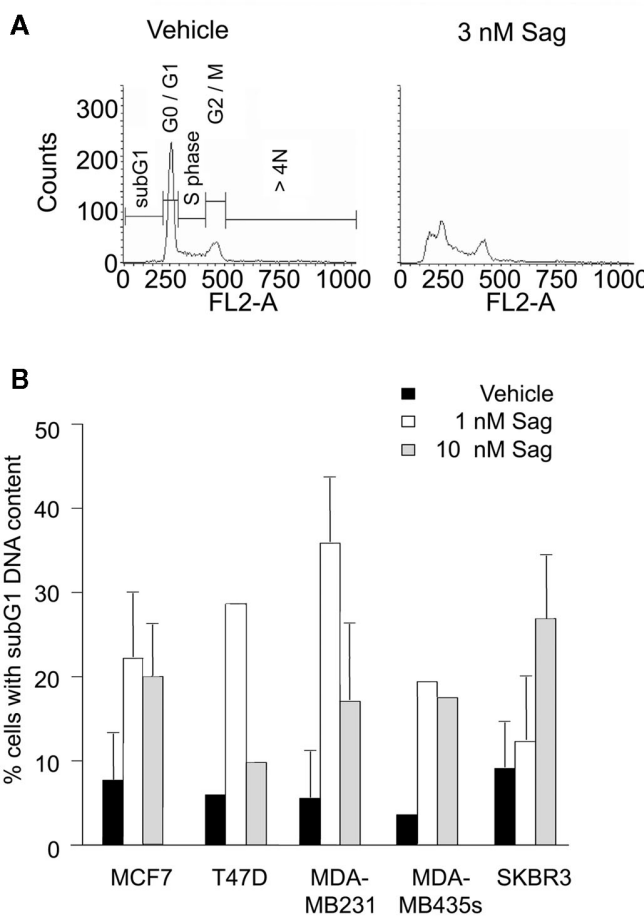

FIGURE 3 | Effect of sagopilone on cell cycle distribution of breast cancer cells. (A) Cell cycle distribution of MDA-MB-231 cells treated with vehicle (ethanol), 3, 10, or $40 \mathrm{nM}$ sagopilone (Sag) for $20 \mathrm{~h}$. (B) Percentages of cells with subG1 DNA content (left) and cells in G2-M phase (right) for breast cancer cell lines MDA-MB-231,

sagopilone concentration levels were chosen so that the higher level but not the lower led to mitotic arrest. The screening data are available in the Supplementary Material.

The strongest suppressor effects were observed for the knockdown of components of the SAC (Figure 6A). The knockdown of components of the chromosomal passenger complex INCENP and CDCA8 (Borealin), of the spindle protein CKAP5 (CHTOG) and the mitotic checkpoint kinases BUB1B and MAD2L1 reduced sagopilone-induced mitotic arrest significantly in all four cell lines with at least two of three siRNAs. Knockdown of BUB1 and TTK (MPS1) components of the mitotic checkpoint complex, reduced mitotic arrest significantly in MCF7 and A549 cells but had little or no effect on T47D and MDA-MB-435s cells. The protein CENPE functions both as mitotic kinesin (KIF10) and as signaling component of the SAC. Its knockdown suppressed sagopilone effects in MCF7 and MDA-MB-435s cells. The knockdown of tubulin K-ALPHA1 and kinesin KIF2C (MCAK) resulted in the strongest sensitizing effects in three or four cell lines, respectively (Figure 6B). Other sensitizing gene knockdowns affected only two of four cell lines. A pronounced effect displayed the knockdown of kinesin KIF11 (EG5), which potentiated the sagopilone-induced mitotic arrest in MCF7 and A549 cell lines. None of the genes involved in drug transport and metabolism, apoptosis, cell cycle control other than mitosis, or other functional classes screened showed significant modifier effects in the chosen screening set-up.
$10 \mathrm{nM}$ Sag
$40 \mathrm{nM}$ Sag
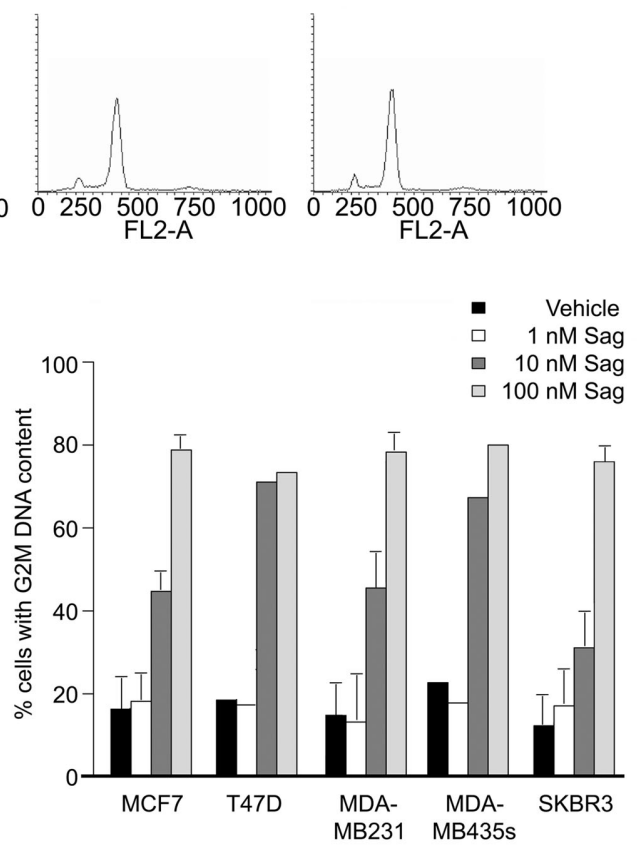

T47D, MCF7, SKBR3, and MDA-MB-435s treated with vehicle (ethanol) or the indicated concentrations sagopilone for $18 \mathrm{~h}$ (20 h for MDA-MB-231). Means and SDs of triplicate experiments are shown for MCF7, MDA-MB-231, and SKBR3 cells. Result of one experiment shown for T47D and MDA-MB-435s cells.

\section{THE KNOCKDOWN OF THE SAC COMPONENTS BUB1B AND CENPE REDUCES SAGOPILONE ACTIVITY}

To validate modifier effects observed for the knockdown of SAC components, the kinases BUB1B and CENPE were chosen. Validation experiments were performed in ER $\alpha$-positive MCF7 and T47D breast cancer, in ER $\alpha$-negative SKBR3 breast cancer (substituting MDA-MB-435s cell line, see Materials and Methods for discussion) and A549 lung cancer cell lines. The experiments aimed to examine the knockdown effect on sagopilone-induced subG1 aneuploidy, sagopilone-induced mitotic arrest, and the inhibition of proliferation by sagopilone (Figure 7A).

siRNA-mediated mRNA knockdown was achieved for both genes with three siRNAs in all four cell lines (Figure 7B). The mRNA knockdown remained stable after $24 \mathrm{~h}$ sagopilone treatment (data not shown). Successful protein knockdown was shown in MCF7 cells (Figure 7C). It was also confirmed that neither BUB1B nor CENPE knockdown on its own influenced the parameters to be measured (Figures 8 and $\mathbf{9}$ ).

To address the influence of BUB1B and CENPE knockdown on the low-dose phenotype of sagopilone, the DNA content of siRNAtransfected cells treated for $24 \mathrm{~h}$ with vehicle or low-dose sagopilone (1 nM) was analyzed (Figure 8). Neither BUB1B nor CENPE knockdown affected sagopilone-induced subG1 aneuploidy in any of the four cell lines.

Next, the influence of BUB1B and CENPE knockdown on sagopilone-induced mitotic arrest was studied by FACS analysis 
A
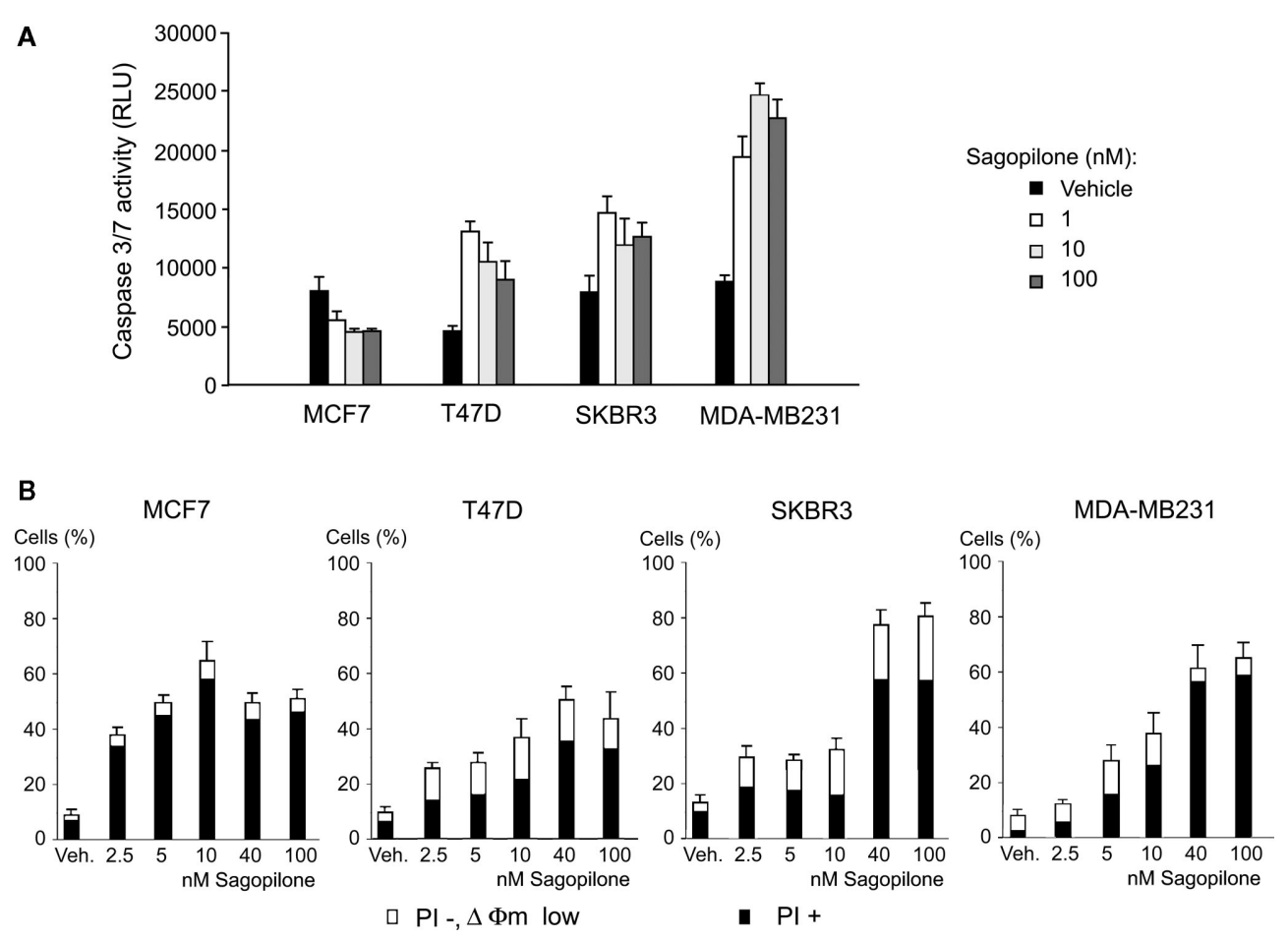

FIGURE 4 | Sagopilone induces caspase activity, loss of mitochondrial membrane potential and loss of vitality in MCF7, T47D, SKBR3, and MDA-MB-231 breast cancer cells. (A) Chemiluminescence-based measurement of caspase $3 / 7$ activity in cell lysates after $48 \mathrm{~h}$ of treatment with either vehicle (ethanol) or sagopilone. RLU, relative light units. Means

and SDs of triplicate experiments are shown. (B) The percentages of dead cells $(\mathrm{PI}+$, black) and vital cells characterized by loss of mitochondrial membrane potential ( $\mathrm{PI}-, \Delta \Psi \mathrm{m}$ low, white) were determined following treatment with vehicle (ethanol) or indicated concentrations of sagopilone for $72 \mathrm{~h}$. Mean percentages and SDs given $(n=2)$.
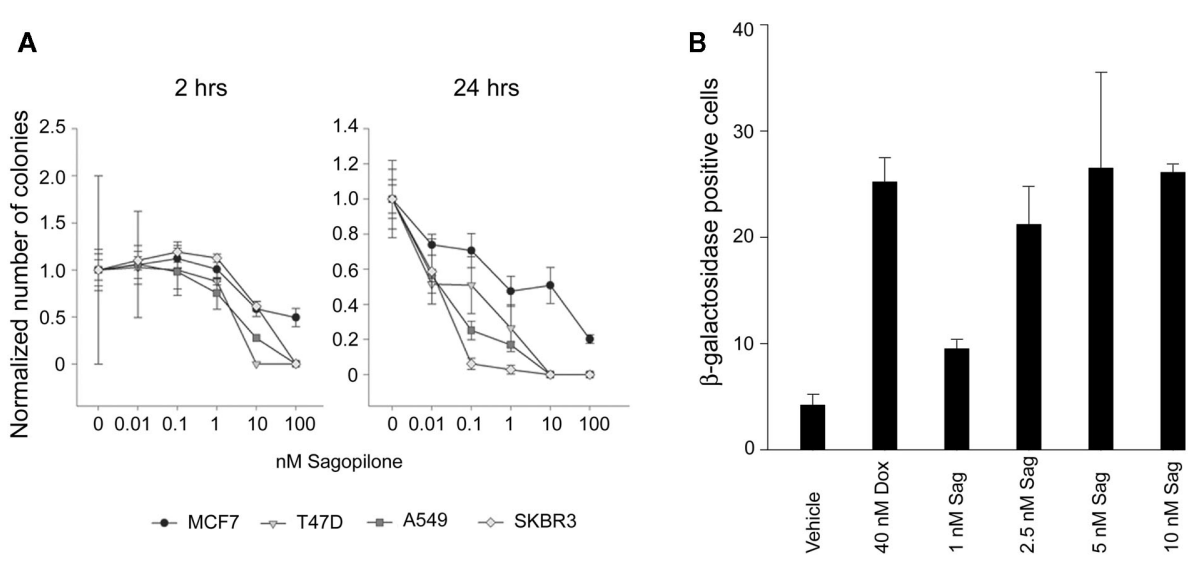

FIGURE 5 | Sagopilone reduces colony formation and induces senescence. (A) Clonogenic assays in MCF7, T47D, SKBR3 breast cancer and A549 lung cancer cells. Sagopilone was added $24 \mathrm{~h}$ after seeding for either $2 \mathrm{~h}$ (left) or $24 \mathrm{~h}$ (right). Afterward, cells were cultured without sagopilone for additional 10-14 days. Colonies were fixed with glutaraldehyde, stained with crystal violet, and counted. The number of colonies obtained under sagopilone treatment was normalized to the number of colonies in vehicle-treated samples. Means and SDs of triplicate experiments are given. (B) Senescence assay in T47D breast cancer cells. Sagopilone (Sag), doxorubicin (Dox, positive control), or vehicle (ethanol) were added $24 \mathrm{~h}$ after seeding of cells for 6 days. Cells were fixed and treated with $X$-gal for staining of $\beta$-galactosidase. The percentage of $\beta$-galactosidase-positive cells was calculated. Means and SDs of triplicate measurements are given. of the DNA content of cells treated for $24 \mathrm{~h}$ with vehicle or sagopilone (1, $40 \mathrm{nM}$; Figure 9). The knockdown of both genes reduced the sagopilone-induced mitotic arrest in MCF7, T47D, and SKBR3 cells. This effect was not visible in A549 cells, likely due to saturation of the mitotic arrest at the applied sagopilone concentration. Using microscopic evaluation of phospho-histone 


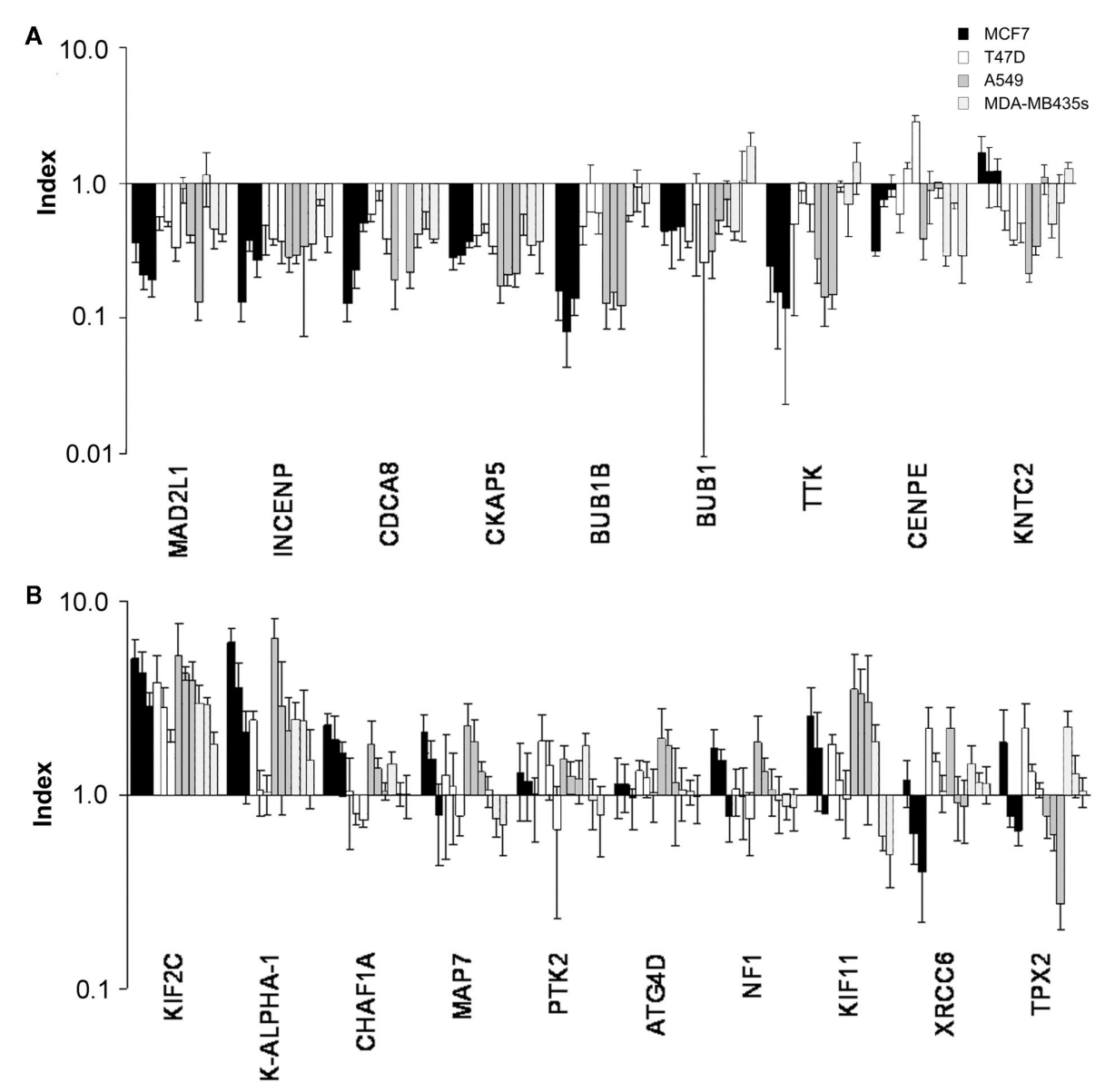

FIGURE 6 | Top candidate modifiers in RNAi sagopilone modifier screen. The modifier effect of RNAi-mediated knockdown on sagopilone-induced mitotic arrest was analyzed for over 300 genes in MCF7, T47D, A549, and MDA-MB-435s cell lines with three different siRNAs per gene. Controls and transfected cells were treated with vehicle, low-dose, and high-dose sagopilone. Screening conditions, data analysis, and ranking of modifier effects are detailed in Section "Materials and Methods."

Index $>1=$ enhancement of sagopilone effects, index $<1=$ suppression of sagopilone effects. (A) Strongest suppressor effects (index calculated for high-dose treatment). (B) Strongest sensitizer effects (index calculated for low-dose treatment). Both panels ranked according to strength of modifier effect. positive nuclei, the reduction of sagopilone-induced mitotic arrest was also demonstrated in A549 cells (data not shown).

Crystal violet-based proliferation assays were chosen to assess the modifier effect on proliferation inhibition (Figure 10). Two parameters were analyzed: $\mathrm{IC}_{50}$ values and survival indices indicative of cells surviving $72 \mathrm{~h}$ treatment with $100 \mathrm{nM}$ sagopilone. It was demonstrated that neither BUB1B nor CENPE knockdown affected $\mathrm{IC}_{50}$ values in any of the four cell lines. In contrast, survival indices were increased for BUB1B knockdown in all four cell lines and for CENPE knockdown in T47D cells.

\section{THE KNOCKDOWN OF THE KINESINS KIF11 AND KIF2C ENHANCES SAGOPILONE ACTIVITY}

In order to validate the modifier effects observed for the knockdown of the mitotic kinesins KIF11 and KIF2C, similar experiments as described above for the SAC components were performed in parallel.

siRNA-mediated mRNA knockdown was achieved for KIF2C using three different siRNAs in all four cell lines (Figure 7B) and remained stable under sagopilone treatment (data not shown). The KIF2C knockdown was also shown on protein level in MCF7 cells (Figure 7C) and did not affect the parameters under question (Figures 8 and 9). Low sagopilone concentrations (1 nM) induced the typical low-dose phenotype of subG1 aneuploidy (Figure 8). The simultaneous knockdown of KIF2C reduced significantly the number of cells with subG1 DNA content. Also, it led to a significant increase in the amount of G2/M cells at low sagopilone concentration ( $1 \mathrm{nM}$; Figure 9). Thus, KIF2C knockdown enhanced sagopilone-induced mitotic arrest. $\mathrm{IC}_{50}$ values and survival indices of proliferation inhibition remained unchanged when KIF2C expression was reduced in all four cell lines (Figure 10).

For KIF11, the mRNA knockdown was only limited for three different siRNAs (Figure 7B). A fourth siRNA, directed against all four KIF11 isotypes, displayed a strong knockdown but also a phenotype with pronounced mitotic arrest and increased lethality. Gene knockdown was also shown on protein level in MCF7 cells (Figure 7C). At $1 \mathrm{nM}$ sagopilone, a significant reduction of sagopilone-induced aneuploidy was seen for KIF11 knockdown 


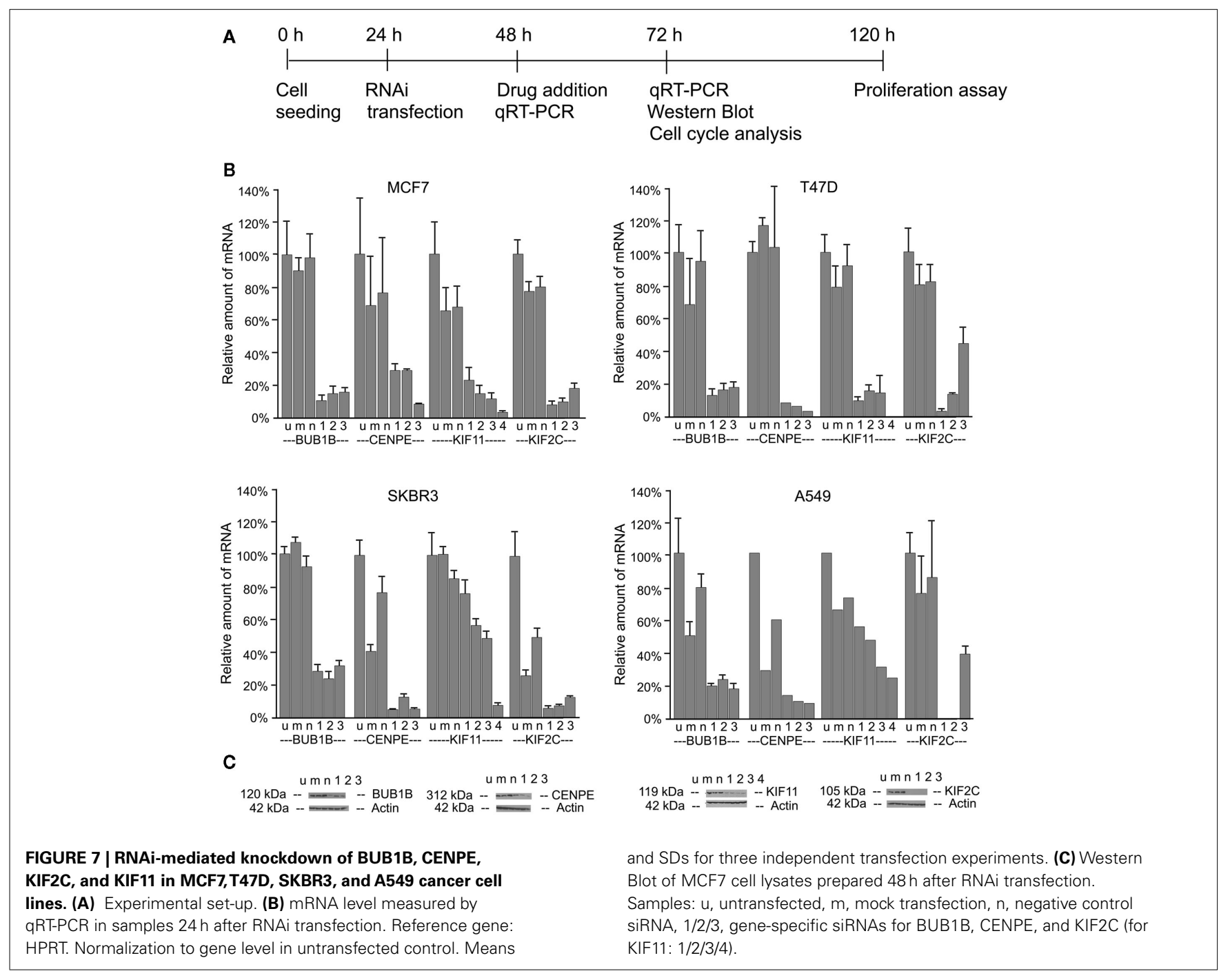

in all cell lines for all siRNAs achieving a significant knockdown (Figure 8). Also, the $\mathrm{IC}_{50}$ values of proliferation inhibition increased relative to controls (mock transfected, negative non-targeting siRNA transfected) after successful KIF11 knockdown but survival indices of proliferation inhibition remained unchanged (Figure 10).

To further elucidate the influence of KIF11 on the induction of aneuploid cells after low-dose sagopilone treatment, we compared the RNAi-mediated knockdown of KIF11 with the effect of ispinesib treatment, a small molecule inhibitor of KIF11 (Purcell et al., 2010). Similar to the RNAi-mediated knockdown of KIF11, ispinesib significantly reduced the sagopilone-induced aneuploidy without increasing mitotic arrest (Figure 11A). The combination of sagopilone and ispinesib had antagonistic effects in proliferation assays of T47D, MCF7, SKBR3, and MDAMB-231 breast cancer cell lines (Figure 11B). Both KIF11 knockdown and KIF11 inhibition caused typical monoasters (Figures 11C,D). Thus, interference with spindle assembly by KIF11 inhibition specifically antagonizes the low-dose sagopiloneinduced aneuploidy but not the sagopilone-induced mitotic arrest.
To conclude, silencing of five out of the 300 RNAi-targeted genes had an antagonistic effect on sagopilone in all four cell lines in the screen (MAD2L1, INCENP, CDCA8, CKAP5, BUB1B); silencing of another four genes had an antagonistic effect in at least two cell models (BUB1, TTK, CENPE, KNTC2). On the other hand, silencing of one out of the 300 genes had a sensitizing effect on sagopilone in all four cell lines (KIF2C); silencing of another five genes had a sensitizing effect in at least two cell models (KIF2C, K-ALPHA1, CHAF1A, MAP7, KIF11). From these candidate modifier target genes, validation studies have so far confirmed modifier effects for four genes (BUB1B, CENPE, KIF11, and KIF2C).

\section{DISCUSSION}

The general cellular and molecular mechanisms of sagopilone, a new epothilone, have been described earlier (Hoffmann et al., 2008). Here we report additional data, confirming that sagopilone produces also rapid cellular effects in breast cancer cell lines, including both $\mathrm{ER} \alpha$-positive and $\mathrm{ER} \alpha$-negative tumors, resulting in considerable anti-proliferative activity, even after short incubation times, due to its fast uptake and high affinity and selectivity to its target $\beta$-tubulin (TUBB1). 
MCF7

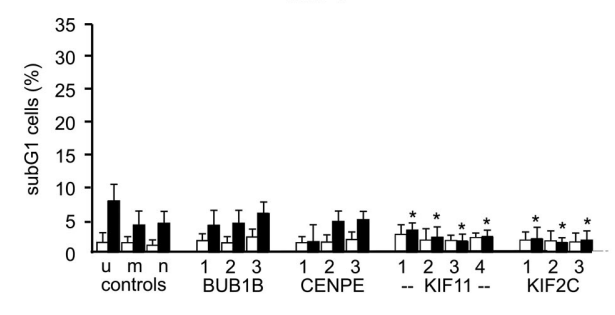

SKBR3

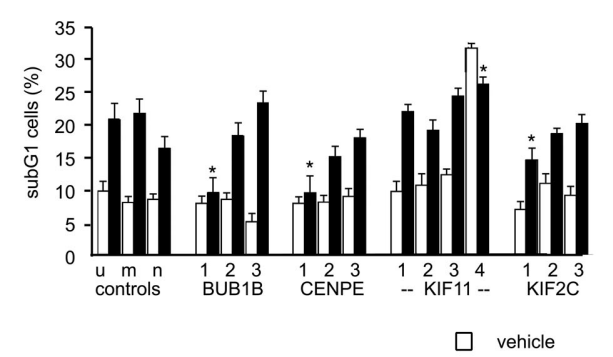

FIGURE 8 | RNAi-mediated knockdown of KIF11 and KIF2C reduces sagopilone-induced aneuploidy. MCF7, T47D, SKBR3, and $A 549$ cancer cells were transfected with siRNAs specific for BUB1B, CENPE, KIF11, or KIF2C. Vehicle or $1 \mathrm{nM}$ sagopilone were added $24 \mathrm{~h}$ post transfection. Cells with subG1 DNA content were quantified by FACS analysis of $\mathrm{Pl}$-stained cells $24 \mathrm{~h}$ post drug addition.
T47D
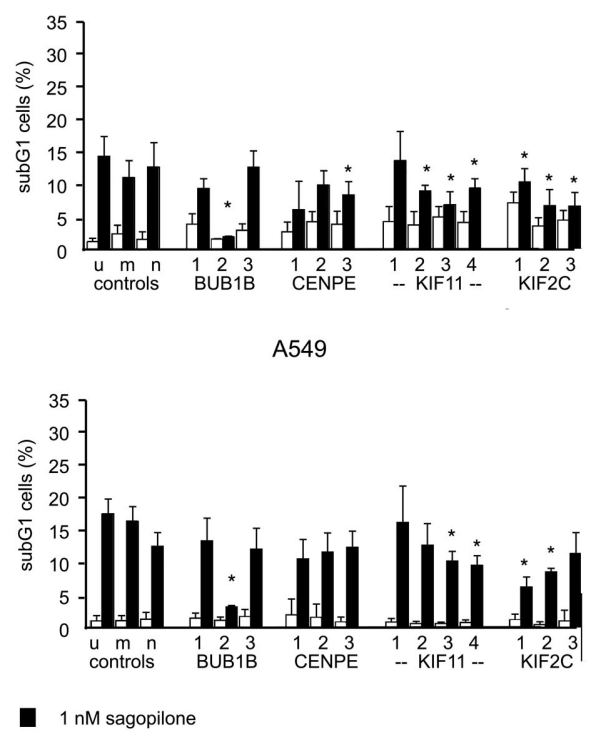

Samples: $u$, untransfected, $m$, mock transfection, $n$, negative control siRNA, 1/2/3, gene-specific siRNAs for BUB1B, CENPE, and KIF2C, for KIF11: $1 / 2 / 3 / 4$. Mean percentages and SDs of three transfection experiments are given. *Marks if $P<0.05$ ( $t$-test, two-sided) for comparison of difference $=$ (drug-treated-untreated) between transfected sample and control (negative siRNA).
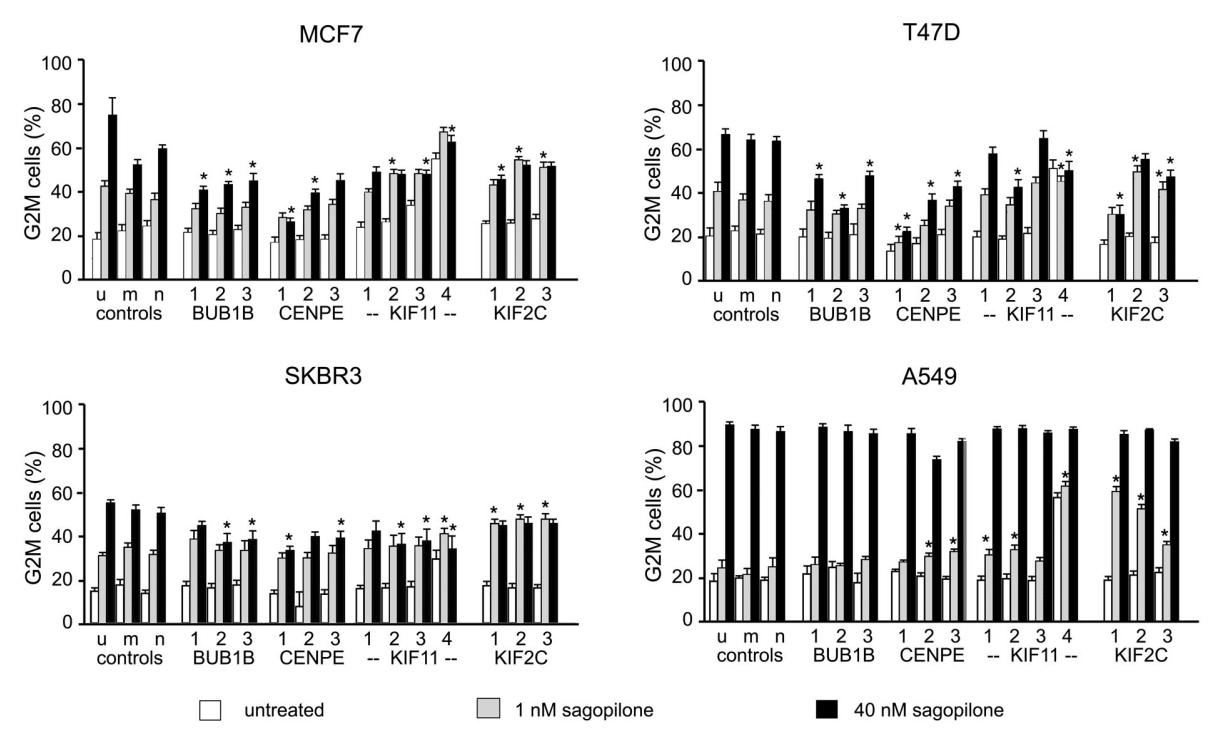

FIGURE 9 | RNAi-mediated knockdown of BUB1B and CENPE reduces sagopilone-induced mitotic arrest while RNAi-mediated knockdown of KIF2C enhances sagopilone-induced mitotic arrest. MCF7, T47D, SKBR3, and A549 cancer cells were transfected with siRNAs specific for BUB1B, CENPE, KIF11, or KIF2C. Vehicle, 1 or $40 \mathrm{nM}$ sagopilone were added $24 \mathrm{~h}$ post transfection. Cells with G2-M-DNA content were quantified by FACS analysis of Pl-stained cells $24 \mathrm{~h}$ post drug addition. Samples: $u$, untransfected, $\mathrm{m}$, mock transfection, $n$, negative control siRNA, $1 / 2 / 3$, gene-specific siRNAs for BUB1B, CENPE, and KIF2C, for KIF11: 1/2/3/4. Mean percentages and SDs of three transfection experiments are given. ${ }^{*}$ Marks if $P<0.05$ ( $t$-test,

two-sided) for comparison of difference $=$ (drug-treated-untreated) between transfected sample and control (negative siRNA).
As seen in other tumor cell lines, the anti-proliferative activity of sagopilone is more potent than that of paclitaxel or ixabepilone across breast cancer cell lines. A retrospective analysis of patient-derived breast cancer tissue has indicated that estrogen receptor $\alpha(E R \alpha)$ positive tumors were more resistant to six anticancer agents than $\mathrm{ER} \alpha$-negative tumors and ixabepilone response 
MCF7

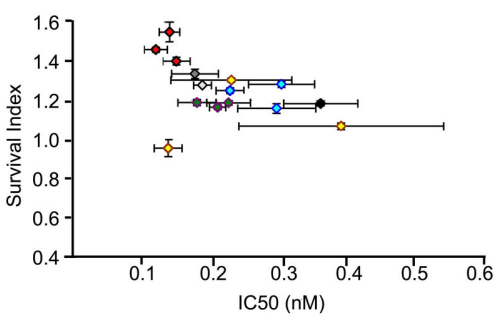

SKBR3

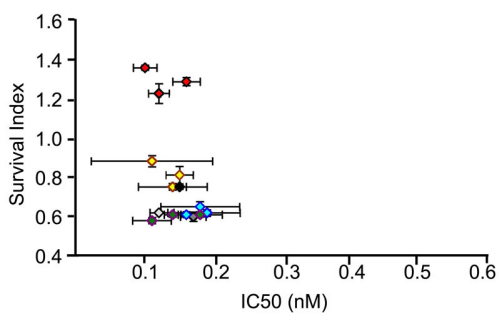

FIGURE 10 | RNAi-mediated knockdown of BUB1B enhances survival of sagopilone-treated cells. MCF7, T47D, SKBR3, and A549 cancer cells were transfected with siRNAs specific for BUB1B, CENPE, KIF11, or KIF2C. Vehicle or sagopilone were added $24 \mathrm{~h}$ post transfection. $I \mathrm{C}_{50}$ and survival index were
T47D

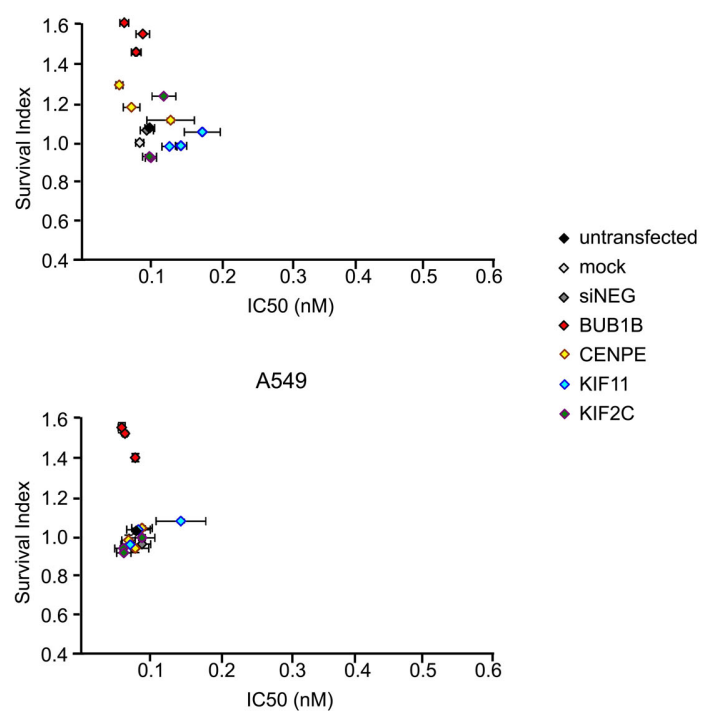

calculated for $72 \mathrm{~h}$ proliferation assays. Samples: u, untransfected, $\mathrm{m}$, mock transfection, $n$, negative control siRNA, 1/2/3, gene-specific siRNAs for BUB1B, CENPE, and KIF2C, for KIF11: 1/2/3/4. No data available for KIF11 \#4 due to high lethality. Means and SDs of three transfection experiments are given.

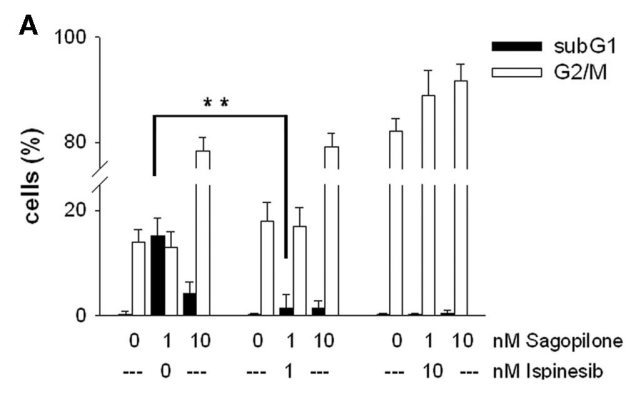

C

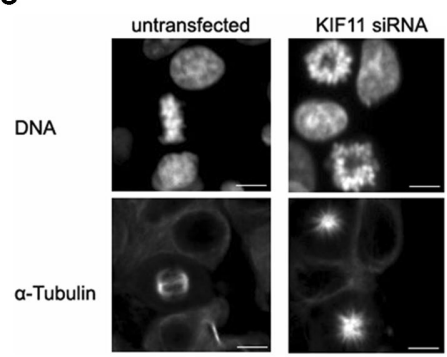

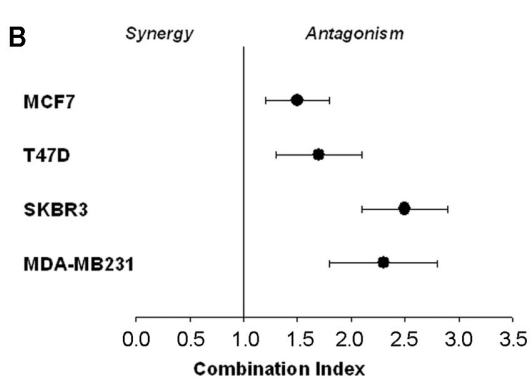

D

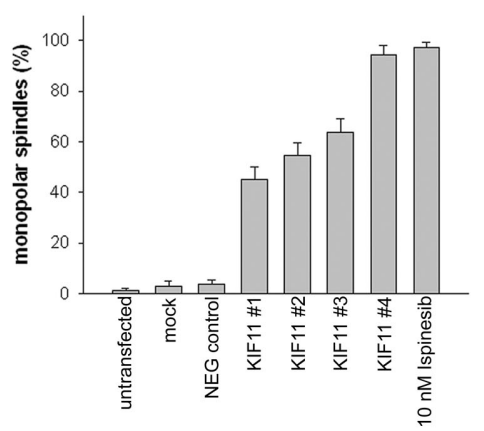

breast cancer cells. Calculation of combination index (Cl) according to Chou (2006). Means and SDs for $\mathrm{Cl}$ from three independent experiments. (C) Induction of monoasters by KIF11 knockdown in MDA-MB-231 cells. Immunofluorescence staining with Hoechst33342 (DNA) and $\alpha$-Tubulin-FITC. Scale bar $=10 \mu \mathrm{m}$. (D) Quantification of monoaster induction by KIF11 knockdown or KIF11 inhibition with ispinesib. Manual count, means, and SDs from triplicate experiments. 
has been associated with low levels of ER $\alpha$ expression (Maehara et al., 1990; Pusztai, 2007). In our study, we show that sagopilone potently inhibited tumor cell proliferation in all ER $\alpha$-positive cell lines. Comparable anti-proliferative effects were observed with sagopilone treatment of ER $\alpha$-negative tumor cells, suggesting that sagopilone may represent a therapeutic option for $\operatorname{ER} \alpha$-positive tumors, especially in an adjuvant setting or if tumors have become hormone independent.

In the past microtubule-targeting drugs were generally believed to cause mitotic arrest, but more detailed studies have identified two concentration-dependent phenotypes (Torres and Horwitz, 1998; Chen et al., 2003; Winsel et al., 2011). We were able to show that this is also the mode of action of sagopilone in breast cancer cells. At low concentrations $(<5 \mathrm{nM})$, sagopilone affects spindle morphology without causing mitotic arrest. Low sagopilone concentrations lead to the formation of multipolar, yet functional spindles. Multipolar mitosis produces vital cells with reduced, aneuploid DNA content. We demonstrated that siRNA knockdown of SAC components does not affect the sagopilone-induced aneuploidy. The concentration range inducing subG1 aneuploidy also inhibited cell proliferation indicating that subG1 aneuploidy induction may be one mechanism responsible for proliferation inhibition. This is supported by our data on KIF11 inhibition which reduces sagopilone-induced aneuploidy and also antagonizes proliferation inhibition. In part responsible for the inhibition of proliferation may be apoptosis and senescence. We show loss of mitochondrial membrane potential and caspase activation which have been described as hallmarks of sagopilone-induced apoptosis in HCT116 colon cancer cells (Hoffmann et al., 2008). Previously, we have shown in A549 lung cancer cells that the activation of TP53 by low sagopilone concentrations protects cells from apoptosis and leads to G1-like arrest (Winsel et al., 2011). Prolonged G1-like arrest may ultimately lead to senescence as we have shown here. Recently, Weaver and Cleveland (2007) demonstrated that gross aneuploidy leads to tumor suppression. The mechanism of proliferation inhibition by sagopilone-induced subG1 aneuploidy was observed in the breast cancer cell lines MCF7, T47D, MDA-MB231, SKBR3, and MDA-MB-435s independently of ER $\alpha$-status. However, MCF7 cells were to some degree resistant, retaining certain colony forming capacity even after sagopilone treatment. Of the five cell lines, MCF7 cells display the highest degree of polyploidy, being near tetraploid. Possibly, the risk of cells escaping the G1-arrest or overcoming the drawbacks of gross aneuploidy increases with polyploidy. In addition, MCF7 cells lack the activity of the apical caspase 3 so that apoptosis induction may not be as efficient.

A different phenotype appears to be induced at higher sagopilone concentrations, with progressively more perturbed microtubule dynamics, formation of microtubule bundles and activation of the SAC leading to an arrest in mitosis. Sagopilone-induced mitotic arrest was demonstrated in the breast cancer cell lines MCF7, T47D, MDA-MB-231, SKBR3, and MDA-MB-435s independently of ER $\alpha$-status. Following mitotic arrest, we observed the induction of caspase 3/7 activity (not in caspase 3-deficient MCF7 cells) and loss of mitochondrial membrane potential. This indicates induction of mitochondrial apoptosis substantially similar to that seen with paclitaxel and other epothilones (Hoffmann et al.,
2008). Recently, it was demonstrated that the extent of apoptosis following mitotic arrest may vary according to differences in apoptotic signaling (Shi et al., 2008). Other exits from prolonged mitotic arrest include aberrant mitosis, mitotic slippage, and endoreduplication. Near tetraploidy, prove of previous aberrant mitotic events, and weakened apoptotic efficiency due to caspase 3 deficiency may explain the low, yet persistent colony forming ability of MCF7 cells even after $24 \mathrm{~h}$ treatment with $100 \mathrm{nM}$ sagopilone. Nonetheless, so far we did not succeed in raising any sagopilone-resistant clone in vitro.

Furthermore, results of the RNAi drug modifier screen underlined that the function of the SAC determines sagopilone activity. Of the 300 genes that were screened, mainly candidate genes involved in SAC exhibited modifier effects in all four cell lines. Neither drug transport, metabolic genes nor other previously described mechanisms of paclitaxel resistances influenced sagopilone action. Within the short observation time and the chosen screening set-up, the previously published importance of proapoptotic genes for sagopilone-induced apoptosis (Hoffmann et al., 2008) was not seen.

Mitotic spindle formation is fundamental to mitosis and therefore it would be expected that components of this process have an impact on the antitumor activity of microtubule-targeting drugs. The SAC postpones anaphase until all kinetochores are attached to both spindle poles (Zhou et al., 2002; Musacchio and Salmon, 2007). If the SAC is weakened by mutation or gene knockdown, cells can continue with mitosis without complete kinetochore attachment or exit aberrantly from mitosis after arrest without subsequent apoptosis (Tao et al., 2005). This has been confirmed in experiments where important SAC components, i.e., BUB1B and CENPE, have been knocked down and suppression of sagopilone-induced mitotic arrest and increased cell survival was observed in several breast cancer cell lines. The dysfunction of SAC components has previously been shown to generate paclitaxel resistance (Carvalho et al., 2003; Sudo et al., 2004; Swanton et al., 2007; Weaver and Cleveland, 2007). Interestingly, clinical paclitaxel resistance in colorectal cancer has been linked to CIN, which is associated with the abnormal expression of certain SAC regulators (Swanton et al., 2006; Harrison and Swanton, 2008). Incidentally, mutations in CIN genes have been linked to increased mortality in breast cancer patients (Brendle et al., 2008). The influence of CIN on sagopilone activity in the clinic, however, remains to be determined.

Mitotic kinesins are required for spindle formation and chromosome alignment and thus central to fulfilling SAC demands. In phase I of mitosis, centrosomes are separated by the KIF11 (EG5) motor function (Zhu et al., 2005). Inhibition of KIF11 by RNAi-mediated knockdown or synthetic inhibitor reduced sagopilone-induced spindle multipolarity and subsequent aneuploidy. On the other hand, sagopilone countered the monopolarity caused by KIF11 inhibition. Our data suggest, that sagopilone induces ectopic spindle poles as described for epothilone B (Sakaushi et al., 2008). These ectopic spindle poles are independent from microtubule-organizing centers. Due to their spatial distribution, KIF11 activity is not required for the formation of functional bipolar spindles. At the same time, KIF11 inhibition hinders the separation of the true spindle pole. Thus, as 
demonstrated here, the combined influence of KIF11 inhibition and sagopilone re-establishes bipolar mitosis. In conclusion, the reduction of sagopilone-induced aneuploidy, one of the mechanisms of proliferation inhibition, is the molecular basis for the antagonism measured here in proliferation assays for the combination of ispinesib and sagopilone. Recently, the combination of docetaxel and ispinesib showed acceptable toxicity profiles without pharmacokinetic drug interaction in a phase I trial (Blagden et al., 2008). However, based on our molecular data, one would not expect synergism between these drugs.

KIF2C (MCAK) plays a role in phase II of mitosis during chromosome alignment and congression (Zhu et al., 2005). Its knockdown reduced the sagopilone concentration required for mitotic arrest. We hypothesize that the knockdown increases SAC signaling thus synergizing with sagopilone. Recently, it has been reported that cancer cells are more sensitive to KIF2C RNAimediated knockdown than normal cells and that the knockdown potentiates paclitaxel-induced mitotic arrest (Hedrick et al., 2008). Furthermore, KIF2C is upregulated in breast cancer (Shimo et al., 2008). Thus, KIF2C inhibition seems to be a valuable combination strategy for sagopilone. The only KIF2C inhibitors known so far, sulfoquinovosylacylglycerols, also inhibit DNA polymerases (Aoki et al., 2005) and have therefore not been evaluated in combination.

Summarizing the new experimental data, sagopilone shows superior activity across a range of heterogeneous breast cancer models compared with other anticancer agents, including established (paclitaxel) and recently approved (ixabepilone) breast cancer treatments. In all breast cancer models studied here, the same sagopilone phenotypes were observed. Proliferation inhibition due to aneuploid cell divisions at low-dose was superseded by mitotic arrest and apoptosis at higher doses. Key modulator of sagopilone activity was the SAC. Drug combination synergism is likely to result from combined activation of the SAC. Therefore, the SAC activity status (i.e., expression levels, polymorphisms, mutations), especially of the central SAC kinase BUB1B, could potentially define patient sub-populations for a more tailored drug treatment.

\section{MATERIALS AND METHODS CELLS AND COMPOUNDS}

Human cancer cell lines were obtained from the American Type Culture Collection (ATCC), except for MX-1 (DKFZ, Heidelberg, Germany), EVSA-T (DSMZ, Braunschweig, Germany), and SUM149 (Steven Ethier, University of Michigan Medical Center, MI, USA). The cancer cell line MDA-MB-435s was also obtained from the ATCC. MDA-MB-435s cancer cells were originally isolated from the pleural effusion of a 31-year-old female with metastatic, ductal adenocarcinoma of the breast (Cailleau et al., 1978). However, recent studies questioned the origin of the parental cell line, MDA-MB-435. In gene expression microarray analysis MDA-MB-435 clustered with cell lines of melanoma origin instead of breast cancer origin and MDA-MB-435 has been reported to be cross-contaminated with the M14 melanoma line (Chambers, 2009). Microsatellite analysis confirmed that the cell lines were identical (Hollestelle and Schutte, 2009). However, Hollestelle et al. also showed that several basal type breast cancer cell lines have a genetic basis similar to melanoma. Thus, they conclude that both MDA-MB-435 and M14 are breast cancer cell lines of basal type (Hollestelle et al., 2009). The discussion of the MDA$\mathrm{MB}-435 \mathrm{~s}$ origin was ongoing during the time of the performance of the work presented here. For this reason, we substituted in some experiments the MDA-MB-435s cell line with the SKBR3 cell line, which is also $\mathrm{ER} \alpha$-negative.

Subconfluent tumor cells were cultured according to standard protocols. For cells obtained from the ATCC or DKFZ, recommended protocols were used. Cells obtained from the DSMZ were passaged in RPMI 1640 medium and SUM149 cells were cultured as previously described (Forozan et al., 1999).

Sagopilone (Klar et al., 2006), patupilone ixabepilone, and ispinesib were synthesized at Bayer Healthcare Pharmaceuticals (Berlin, Germany) through total syntheses. Paclitaxel and doxorubicin were purchased from Sigma-Aldrich (Munich, Germany). All substances were dissolved in ethanol, except for doxorubicin which was dissolved in $\mathrm{H}_{2} \mathrm{O}$. All media and supplements for cell culture were purchased from Biochrom AG (Berlin, Germany). Stock solutions were prepared as previously described (Lichtner et al., 2001).

\section{IN VITRO ANALYSIS OF SAGOPILONE ON TUMOR CELL PROLIFERATION, CYTOSKELETON, CELL CYCLE, APOPTOSIS, AND SENESCENCE}

The effect of sagopilone and other anticancer agents on the proliferation of breast cancer cell lines was assessed using a cell proliferation assay based on crystal violet cell staining as described before (Lichtner et al., 2001). IC $_{50}$ values were calculated from three independent experiments using the SigmaPlot software (SPSS, Friedrichsdorf, Germany). The survival index was calculated as ratio of cell number surviving a 72 -h treatment with $100 \mathrm{nM}$ sagopilone divided by initial cell number (Shi et al., 2008). The combined effect of sagopilone and ispinesib was measured in cell proliferation assays. Here, the combination index (CI) was calculated according to Chou (2006).

To visualize the effects of sagopilone on mitotic and interphase microtubules, MDA-MB-231 cells were incubated with vehicle (ethanol), 3 or $40 \mathrm{nM}$ sagopilone for $20 \mathrm{~h}$, fixed with $4 \%$ paraformaldehyde, and stained with a monoclonal mouse anti$\alpha$-tubulin antibody (1:1000; Sigma-Aldrich, Munich, Germany), Alexa Fluor ${ }^{\circledR} 488$ goat anti-mouse IgG secondary antibody (1:250; Invitrogen Inc., Carlsbad, CA, USA), and DRAQ5 ${ }^{\mathrm{TM}}$ (Biostatus, Leicestershire, UK), according to standard protocols. Fixed and stained cells were analyzed using a Zeiss LSM 510 META microscope (Carl Zeiss AG, Jena, Germany) equipped with a PlanApochromat ${ }^{\circledR} 63 \times / 1.4$ (oil DIC) objective. Zeiss LSM software (version 3.0 SP3) was employed for confocal imaging. Alternatively, cells were stained with mouse anti- $\alpha$-Tubulin-FITC (1:200; SIGMA-Aldrich) and Hoechst33342 (Invitrogen Inc., Carlsbad, CA, USA). Images were taken on the OPERA automated microscope (Evotec, Hamburg, Germany; 10× objective, binning_2) and analyzed using MetaXpress Software (Molecular Devices, Sunnyvale, CA, USA).

Fluorescence-activated cell sorter analysis was performed to determine the distribution of cells in the cell cycle phases. Cells were incubated with sagopilone for $20 \mathrm{~h}$, fixed with $70 \%$ ethanol, and stained with $50 \mu \mathrm{g} / \mathrm{mL}$ propidium iodide (PI; Sigma-Aldrich, 
Munich, Germany). Cellular DNA content was determined by flow cytometry using the BD FACSCalibur ${ }^{\mathrm{TM}}$ and statistically analyzed using CellQuest ${ }^{\mathrm{TM}}$ software (Becton, Dickinson and Company, San Jose, CA, USA).

The activity of the apical caspases 3 and 7 was measured using a commercial chemiluminescence-based caspase 3/7-Kit (Promega, Madison, WI, USA). Cells were seeded at a density of 1000 cells/well in 96-well plates. At $24 \mathrm{~h}$ after cell seeding, sagopilone or vehicle were added. After $48 \mathrm{~h}$ of treatment, cells were lysed, and caspase $3 / 7$ activity was measured according to manufacturer's instructions.

To investigate loss of mitochondrial membrane potential and cellular vitality, breast cancer cells were incubated continuously for $72 \mathrm{~h}$ with vehicle or the indicated drug concentration of sagopilone, trypsinized, stained with 3,3'-dihexyloxacarbocyanine iodide (DiOC6(3); Invitrogen Inc., Carlsbad, CA, USA) and propidium iodide as before (Castedo et al., 2002), measured by flow cytometry using the BD FACSCalibur ${ }^{\mathrm{TM}}$ and statistically analyzed using CellQuest ${ }^{\mathrm{TM}}$ software (Becton, Dickinson and Company, San Jose, CA, USA).

The amount of cellular senescence was determined based on the expression of senescence-associated $\beta$-galactosidase (Dimri et al., 1995) using the Senescence Cells Histochemical Stain Kit (SigmaAldrich, Munich, Germany). At $24 \mathrm{~h}$ after cell seeding, sagopilone was added for 6 days. Doxorubicin was used as positive control (Eom et al., 2005). Cells were fixed and treated with X-gal for staining of $\beta$-galactosidase according to manufacturer's instructions. Stained and unstained cells were counted and the percentage of $\beta$-galactosidase-positive cells was calculated.

\section{RNA INTERFERENCE ANALYSES IN BREAST TUMOR MODELS}

A non-redundant gene list was compiled from the following sources: genes previously seen to be regulated by sagopilone or paclitaxel (Hammer et al., 2010; Winsel et al., 2011), genes previously described as predictors for paclitaxel and/or docetaxel sensitivity (Bergstralh and Ting, 2006; Potti et al., 2006; Swanton et al., 2007), genes reported in CIN signatures (Kim et al., 2004), and genes with the following gene ontology annotations: drug transport, drug metabolism, tubulin, SAC, cell cycle control, or microtubule-associated proteins (http://www.ebi.ac.uk/GOA). The relative expression of 792 genes was analyzed in the three breast cancer cell lines MCF7, T47D, and MDA-MB-435s and the lung cancer cell line A549 in the in-house Array Northern database based on results from by Affymetrix HGU133Plus2.0 arrays, and only genes with significant expression in at least two of the four cell lines were retained. These 300 genes were targeted with three individual siRNAs per gene obtained from Ambion (Austin, TX, USA, see Supplementary Material for detailed information). The effects of gene knockdown in presence and absence of sagopilone were then determined. The percentage of nuclei with condensed chromatin after $24 \mathrm{~h}$ of sagopilone treatment was defined as endpoint of the screen. In preliminary experiments this has been established to reflect the mitotically arrested cell population. For the screen, cells were seeded at $1.5 \times 10^{3}$ (A549), $2 \times 10^{3}$ (MCF7, MDA-MB-435s) or $4.5 \times 10^{3}$ (T47D) cells/well in collagen I coated (except MDA-MB-435s) 384-well microplates (Greiner Bio-One GmbH, Frickenhausen,
Germany) and transfected after $24 \mathrm{~h}$ with $0.076 \mu \mathrm{L}$ DharmaFECT $^{\circledR} 2$ (Dharmacon, Inc., Lafayette, CO, USA) and $100 \mathrm{nM}$ siRNA in serum-containing medium. After $24 \mathrm{~h}$, transfected cells were incubated for $24 \mathrm{~h}$ with medium containing vehicle or medium containing sagopilone at two different concentrations each ( 8 and $20 \mathrm{nM}$ for MCF7 and A549; 3 and $10 \mathrm{nM}$ for T47D and MDA-MB-435s), followed by paraformaldehyde fixation and staining with Hoechst33342 (Invitrogen Inc., Carlsbad, CA, USA). Imaging was performed on an MDC ImageXpressMicro ${ }^{\mathrm{TM}}$ automated microscope (Molecular Devices, Sunnyvale, CA, USA; 10× objective, binning_1, 4 sites/well), and Definiens ${ }^{\circledR}$ software (Definiens AG, Munich, Germany) was used for image analysis.

Each measurement was performed in triplicate. For each treatment (vehicle, low level sagopilone, high level sagopilone), the mean percentage per triplicate measurement of nuclei with condensed chromatin was normalized to the sample median of the treatment level. Normalized means and SDs of triplicate measurement for each siRNA and each treatment level are listed in the Supplementary Material. The modifier effect of an siRNA was graphically presented as index calculated by dividing the normalized means of sagopilone-treated samples by the normalized means of vehicle-treated samples. Thus, an index greater than one indicates that the given siRNA enhanced sagopilone activity, an index smaller than one that the given siRNA reduced sagopilone activity. Modifier effects were ranked according to the following procedure: $t$-values were calculated for each siRNA, comparing sagopilone-treated and vehicle-treated samples. All $t$-values belonging to a certain sagopilone concentration and cell line were ranked in increasing order. Rank sums were calculated for any combination of two out of the three siRNAs per gene. For candidate suppressors, the maximum rank sums for high sagopilone concentrations were ranked in decreasing order, for candidate sensitizers, the minimum rank sums for low sagopilone concentrations were ranked in increasing order.

The following siRNAs from Ambion (Austin, TX, USA) were used for validation experiments: BUB1B (\#88, \#89, \#90), CENPE (\#121337, \#121338, \#121339), KIF2C (\#118444,\#118445, \#118446), KIF11 (\#118429, \#118430, \#118431, \#s7902), negative control siRNA (\#D001210-03-20). $10^{6}$ cells were electroporated in the presence of $1 \mu \mathrm{M}$ siRNA using the Nucleofector I (AMAXA, Cologne, Germany) according to manufacturer's instructions. Transfected cells were then plated at $1 \times 10^{3}$ cells/well in 96well plates for proliferation assays, at $2 \times 10^{4}$ cells/well in 6wellplates (TPP, Trasadingen, Switzerland) for RNA extraction and cell cycle analysis and at $5 \times 10^{3}$ cells/well in $\mu$ CLEAR black 96-well plates (Greiner Bio-One $\mathrm{GmbH}$, Frickenhausen, Germany) for immunofluorescence staining. Sagopilone was added $24 \mathrm{~h}$ post transfection. RNA extraction and fixation for both cell cycle analysis and immunofluorescence staining were done $24 \mathrm{~h}$ post sagopilone addition, while proliferation assay plates were fixed $72 \mathrm{~h}$ post sagopilone addition. RNA was extracted using the RNeasy Mini Kit (Qiagen, Hilden, Germany) and cDNA was generated using SuperScript First Strand Synthesis System (Invitrogen Inc., Carlsbad, CA, USA). Real-Time qRTPCR was performed with gene expression assays from Applied 
Biosystems (Foster City, CA, USA): BUB1B (\#Hs00176169_m1), CENPE (\#Hs00199232_m1), KIF2C (\#Hs00156507_m1), KIF11 (Hs00189698_m1), and GAPDH (\#4326317E). Reactions were set-up in triplicates using the TaqMan FAST Universal PCR Mastermix and recorded in a 7500 Fast Real-Time PCRSystem (Applied Biosystems, Foster City, CA, USA). For detection of protein knockdown the following primary antibodies were used: mouse anti-human BUB1B \#612502 (BD Transduction Laboratories, San Jose, CA, USA), rabbit anti-human CENPE \#C7480 (Sigma-Aldrich, Munich, Germany), mouse antihuman EG5 \#627802 (BioLegend, San Diego, CA, USA), rabbit anti-human MCAK \#NB 100-2589 (Novus Biologicals, Littleton, CO, USA).

\section{REFERENCES}

Aoki, S., Ohta, K., Yamazaki, T., Sugawara, F., and Sakaguchi, K. (2005). Mammalian mitotic centromereassociated kinesin (MCAK): a new molecular target of sulfoquinovosylacylglycerols novel antitumor and immunosuppressive agents. FEBS J. 272, 2132-2140.

Bergstralh, D. T., and Ting, J. P.Y. (2006). Microtubule stabilizing agents: their molecular signaling consequences and the potential for enhancement by drug combination. Cancer Treat. Rev. 32, 166-179.

Blagden, S. P., Molife, L. R., Seebaran, A., Payne, M., Reid, A. H., Protheroe, A. S., Vasist, L. S., Williams, D. D., Bowen, C., Kathman, S. J., Hodge, J. P., Dar, M. M., de Bono, J. S., and Middleton, M. R. (2008). A phase I trial of ispinesib, a kinesin spindle protein inhibitor, with docetaxel in patients with advanced solid tumours. Br. J. Cancer 98, 894-899.

Brendle, A., Brandt, A., Johansson, R., Enquist, K., Hallmans, G., Hemminki, K., Lenner, P., and Forsti, A. (2008). Single nucleotide polymorphisms in chromosomal instability genes and risk and clinical outcome of breast cancer: a Swedish prospective case-control study. Eur. J. Cancer 45, 435-442.

Cailleau, R., Olivé, M., and Cruciger, Q. V. (1978). Long-term human breast carcinoma cell lines of metastatic origin: preliminary characterization. In vitro 14, 911-915.

Carvalho, A., Carmena, M., Sambade, C., Earnshaw, W. C., and Wheatley, S. P. (2003). Survivin is required for stable checkpoint activation in taxoltreated HeLa cells. J. Cell. Sci. 116, 2987-2998.

Castedo, M., Ferri, K., Roumier, T., Metivier, D., Zamzami, N., and Kroemer, G. (2002). Quantitation of mitochondrial alterations associated with apoptosis. J. Immunol. Methods 265, 39-47.
Chambers, A. F. (2009). MDA-MB-435 and M14 cell lines: identical but not M14 melanoma? Cancer Res. 69, 5292-5293.

Chen, J. G., Yang, C. P., Cammer, M., and Horwitz, S. B. (2003). Gene expression and mitotic exit induced by microtubule-stabilizing drugs. Cancer Res. 63, 7891-7899.

Chou, T. C. (2006). Theoretical basis, experimental design, and computerized simulation of synergism and antagonism in drug combination studies. Pharmacol. Rev. 58, 621-681.

Dimri, G. P., Lee, X., Basile, G., Acosta, M., Scott, G., Roskelly, C., Medrano, E. E., Linskens, M., and Rubelj, I. (1995). A biomarker that identifies senescent human cells in culture and aging skin. Proc. Natl. Acad. Sci. U.S.A. 92, 9363. Goo, M. J., Kwon, H. J., Sohn, S., Kim, W. H., Yoon, G., and Choi, K. S. (2005). Two distinct modes of cell death induced by doxorubicin: apoptosis and cell death through mitotic catastrophe accompanied by senescence-like phenotype. Onco-

Forozan, F., Veldman, R., Ammerman, C., Parsa, N., Kallioniemi, A., Kallioniemi, O., and Ethier, S. (1999). Molecular cytogenetic analysis of 11 new breast cancer cell lines. Br. J. Cancer 81, 1328-1334.

Gonzalez-Angulo, A., Morales-Vasquez, F., and Hortobagyi, G. (2007). Overview of resistance to systemic therapy in patients with breast cancer. Adv. Exp. Med. Biol. 608, 1-22.

Groth-Pedersen, L., Ostenfeld, M., Høyer-Hansen, M., Nylandsted, J., and Jäättelä, M. (2007). Vincristine induces dramatic lysosomal changes and sensitizes cancer cells to lysosomedestabilizing siramesine. Cancer Res. 67, 2217-2225.

Hammer, S., Sommer, A., Fichtner, I., Becker, M., Rolff, J., Merk, J., Klar, U., and Hoffmann, J. (2010). Comparative profiling of
Eom, Y. W., Kim, M. A., Park, S. S., gene 24, 4765-4777.

\section{ACKNOWLEDGMENTS}

The authors would like to thank Christophe Echeverri, Cecilie Martin, and Carlo Jochems from Cenix BioScience $\mathrm{GmbH}$ for their contributions to the RNAi screen, funded by Bayer Healthcare Pharmaceuticals, and Philip Denner for scientific discussions and help on fluorescence microscopy. We would also thank Klaus Bosslet and Dominik Mumberg for scientific and administrative support.

\section{SUPPLEMENTARY MATERIAL}

The Supplementary Material for this article can be found online at https://www.frontiersin.org/molecular_and_cellular_oncology/ 10.3389/fonc.2011.00044/abstract

the novel epothilone, sagopilone, in xenografts derived from primary non-small cell lung cancer. Clin. Cancer Res. 16, 1452-1465.

Harrison, M., and Swanton, C. (2008). Epothilones and new analogues of the microtubule modulators in taxane-resistant disease. Expert Opin. Investig. Drugs 17, 523-546.

Hatake, K., Tokudome, N., and Ito, Y. (2007). Next generation molecular targeted agents for breast cancer: focus on egfr and vegfr pathways. Breast Cancer 14, 132-149.

Hedrick, D. G., Stout, J. R., and Walczak, C. E. (2008). Effects of antimicrotubule agents on microtubule organization in cells lacking the kinesin-13 MCAK. Cell Cycle 7, 2146-2156.

Hoffmann, J., Vitale, I., Buchmann, B., Galluzzi, L., Schwede, W., Senovilla, L., Skuballa, W., Vivet, S., Lichtner, R. B., Vicencio, J. M., Panaretakis, T., Siemeister, G., Lage, H., Nanty, L., Hammer, S., Mittelstaedt, K., Winsel, S., Eschenbrenner, J., Castedo, M., Demarche, C., Klar, U., and Kroemer, G. (2008). Improved cellular pharmacokinetics and pharmacodynamics underlie the wide anticancer activity of sagopilone. Cancer Res. 68, 5301-5308.

Hollestelle, A., Nagel, J. H., Smid, M., Lam, S., Elstrodt, F., Wasielewski, M., Ng, S. S., French, P. J., Peeters, J. K., Rozendaal, M. J., Riaz, M., Koopman, D. G., Ten Hagen, T. L., de Leeuw, B. H., Zwarthoff, E. C., Teunisse, A., van der Spek, P. J., Klijn, J. G., Dinjens, W. N., Ethier, S. P., Clevers, H., Jochemsen, A. G., den Bakker, M. A., Foekens, J. A., Martens, J. W., and Schutte, M. (2009). Distinct gene mutation profiles among luminal-type and basaltype breast cancer cell lines. Breast Cancer Res. Treat. 121, 53-64.

Hollestelle, A., and Schutte, M. (2009). Comment Re: MDA-MB-435 and M14 cell lines: identical but not M14 Melanoma? Cancer Res. 69, 7893.
Horwitz, S., Cohen, D., Rao, S., Ringel, I. Shen, H., and Yang, C. (1993). Taxol: mechanisms of action and resistance. J. Natl. Cancer Inst. Monogr. 15, 55-61.

Huang, J., Li, X., Hilf, R., Bambara, R., and Muyan, M. (2005). Molecular basis of therapeutic strategies for breast cancer. Curr. Drug Targets Immune Endocr. Metabol. Disord. 5, 379-396.

Jordan, M. A., Toso, R. J., Thrower, D., and Wilson, L. (1993). Mechanism of mitotic block and inhibition of cell proliferation by taxol at low concentrations. Proc. Natl. Acad. Sci. U.S.A. 90, 9552-9556.

Jordan, M. A., and Wilson, L. (2004). Microtubules as target for anticancer drugs. Nat. Rev. Cancer 4, 253-265.

Kim, H., Nam, S. W., Rhee, H., Shan Li, L., Ju Kang, H., Hye Koh, K., Kyu Kim, N., Song, J., Tak-Bun Liu, E., and Kim, H. (2004). Different gene expression profiles between microsatellite instability-high and microsatellite stable colorectal carcinomas. Oncogene 23, 6218-6225.

Klar, U., Buchmann, B., Schwede, W., Skuballa, W., Hoffmann, J., and Lichtner, R. B. (2006). Total synthesis and antitumor activity of ZK-EPO: the first fully synthetic epothilone in clinical development. Angew. Chem. Int. Ed. Engl. 45, 7942-7948.

Lichtner, R. B., Rotgeri, A., Bunte, T., Buchmann, B., Hoffmann, J. Schwede, W., Skuballa, W., and Klar, U. (2001). Subcellular distribution of epothilones in human tumor cells. Proc. Natl. Acad. Sci. U.S.A. 98, 11743-11748.

Maehara, Y., Emi, Y., Sakaguchi, Y., Kusumoto, T., Kakeji, Y., Kohnoe, S., and Sugimachi, K. (1990). Estrogenreceptor-negative breast cancer tissue is chemosensitive in vitro compared with estrogen-receptorpositive tissue. Eur. Surg. Res. 22, 50-55. 
Musacchio, A., and Salmon, E. D. (2007). The spindle assembly checkpoint in space and time. Nat. Rev. Mol. Cell Biol. 8, 379-393.

National Comprehensive Cancer Network. (2008). NCCN Clinical Practice Guidelines in Oncology: Breast Cancer. Available at: http://www.nccn.org/professionals/ physician_gls/PDF/breast.pdf

Parkin, D., Bray, F., Ferlay, J., and Pisani, P. (2005). Global cancer statistics, 2002. CA Cancer J. Clin. 55, 74-108.

Perou, C., Sørlie, T., Eisen, M., van de Rijn, M., Jeffrey, S., Rees, C., Pollack, J., Ross, D., Johnsen, H., Akslen, L., Fluge, Ø., Pergamenschikov, A., Williams, C., Zhu, S., Lønning, P., Børresen-Dale, A., Brown, P., and Botstein, D. (2000). Molecular portraits of human breast tumours. Nature 406, 747-752.

Potti, A., Dressman, H. K., Bild, A., Riedel, R. F., Chan, G.,Sayer, R., Cragun, J., Cottrill, H., Kelley, M. J., Petersen, R., Harpole, D., Marks, J., Berchuck, A., Ginsburg, G. S., Febbo, P., Lancaster, J., and Nevins, J. R. (2006). Genomic signatures to guide the use of chemotherapeutics. Nat. Med. 12, 1294-1300.

Purcell, J. W., Davis, J., Reddy, M., Martin, S., Samayoa, K., Vo, H., Thomsen, K., Bean, P., Kuo, W. L., Ziyad, S., Billig, J., Feiler, H. S., Gray, J. W., Wood, K. W., and Cases, S. (2010). Activity of the kinesin spindle protein inhibitor ispinesib (SB-715992) in models of breast cancer. Clin. Cancer Res. 16, 566-576.

Pusztai, L. (2007). Markers predicting clinical benefit in breast cancer from microtubule-targeting agents. Ann. Oncol. 18(Suppl. 12), xii15-xii20.

Risinger, A. L., Giles, F. J., and Mooberry, S. L. (2009). Microtubule dynamics as a target in oncology. Cancer Treat. Rev. 35, 255-261.

Sakaushi, S., Nishida, K., Fukada, T., Senda-Murata, K., Oka, S., and Sugimoto, K. (2008). Differential responses of mitotic spindle pole formation to microtubulestabilizing agents epothilones A and $\mathrm{B}$ at low concentrations. Cell Cycle 7, 477-483.

Shi, J., Orth, J. D., and Mitchison, T. (2008). Cell type variation in responses to antimitotic drugs that target microtubules and kinesin-5. Cancer Res. 68, 3269-3276.

Shimo, A., Tanikawa, C., Nishidate, T., Lin, M. L., Matsuda, K., Park, J. H., Ueki, T., Ohta, T., Hirata, K., Fukuda, M., Nakamura, Y., and Katagiri, T. (2008). Involvement of kinesin family member $2 \mathrm{C} /$ mitotic centromere-associated kinesin overexpression in mammary carcinogenesis. Cancer Sci. 99, 62-70.

Sørlie, T., Perou, C., Tibshirani, R., Aas, T., Geisler, S., Johnsen, H., Hastie, T., Eisen, M., van de Rijn, M., Jeffrey, S., Thorsen, T., Quist, H., Matese, J., Brown, P., Botstein, D., Lønning, P., and Børresen-Dale, A. (2001). Gene expression patterns of breast carcinomas distinguish tumor subclasses with clinical implications. Proc. Natl. Acad. Sci. U.S.A. 98, 10869-10874.

Sudo, T., Nitta, M., Saya, H., and Ueno, N. T. (2004). Dependence of paclitaxel sensitivity on a functional spindle assembly checkpoint. Cancer Res. 64, 2502-2508.

Swanton, C., Marani, M., Pardo, O., Warne, P. H., Kelly, G., Sahai, E., Elustondo, F., Chang, J., Temple, J., Ahmed, A. A., Brenton, J. D., Downward, J., and Nicke, B. (2007). Regulators of mitotic arrest and ceramide metabolism are determinants of sensitivity to paclitaxel and other chemotherapeutic drugs. Cancer Cell 11, 498-512.

Swanton, C., Tomlinson, I., and Downward, J. (2006). Chromosomal instability, colorectal cancer and taxane resistance. Cell Cycle 5, 818-823.

Tao, W., South, V. J., Zhang, Y., Davide, J. P., Farrell, L., Kohl, N. E., SeppLorenzino, L., and Lobell, R. B. (2005). Induction of apoptosis by an inhibitor of the mitotic kinesin KSP requires both activation of the spindle assembly checkpoint and mitotic slippage. Cancer Cell 8, 49-59.

Torres, K., and Horwitz, S. B. (1998). Mechanisms of Taxol-induced cell death are concentration dependent. Cancer Res. 58, 3620-3626.

Wahl, A. F., Donaldson, K. L., Fairchild, C., Lee, F. Y., Foster, S. A., Demers, G. W., and Galloway, D. A. (1996). Loss of normal p53 function confers sensitization to Taxol by increasing G2/M arrest and apoptosis. Nat. Med. 2, 72-79.

Wang, Y., Klijn, J., Zhang, Y., Sieuwerts, A., Look, M., Yang, F., Talantov, D. Timmermans, M., van Meijer, M. E., Yu, J., Jatkoe, T., Berns, E., Atkins, D., and Foekens, J. (2005). Geneexpression profiles to predict distant metastasis of lymph-node-negative primary breast cancer. Lancet 365 , 671-679.

Weaver, B. A., and Cleveland, D. W. (2007). Aneuploidy: instigator and inhibitor of tumorigenesis. Cancer Res. 67, 10103-10105.

Whitehurst, A. W., Bodemann, B. O. Cardenas, J., Ferguson, D., Girard, L., Peyton, M., Minna, J. D., Michnoff, C., Hao, W., Roth, M. G., Xie, X. J., and White, M. A. (2007). Synthetic lethal screen identification of chemosensitizer loci in cancer cells. Nature 446, 825-829.

Winsel, S., Sommer, A., Eschenbrenner, J., Mittelstaedt, K., Klar, U., Hammer, S., and Hoffmann, J. (2011). Molecular mode of action and role of TP53 in the sensitivity to the novel epothilone sagopilone (ZKEPO) in A549 non-small cell lung cancer cells. PLOS ONE 6, e19273. doi:10.1371/journal.pone.0019273

Zhou, J., Panda, D., Landen, J. W., Wilson, L., and Joshi, H. C. (2002). Minor alteration of microtubule dynamics causes loss of tension across kinetochore pairs and activates the spindle checkpoint. $J$. Biol. Chem. 277, 17200-17208.
Zhu, C., Zhao, J., Bibikova, M., Leverson, J. D., Bossy-Wetzel, E., Fan, J. B., Abraham, R. T., and Jiang, W. (2005). Functional analysis of human microtubule-based motor proteins, the kinesins and dyneins, in mitosis/cytokinesis using RNA interference. Mol. Biol. Cell 16, 3187-3199.

Conflict of Interest Statement: S. Winsel, J. Eschenbrenner, K. Mittelstaedt, and $M$. Drosch received research grants from Bayer Healthcare Pharmaceuticals. A. Sommer, U. Klar, S. Hammer, B. Weiss, C. Merz, G. Siemeister and J. Hoffmann are current or former employes of Bayer Healthcare Pharmaceuticals and hold patents on Bayer Healthcare Pharmaceuticals as well as shares of Bayer AG. C. Sachse, M. Hannus and M. Seidel are current or former employes of Cenix BioScience $\mathrm{GmbH}$.

Received: 30 June 2011; accepted: 31 October 2011; published online: 16 November 2011.

Citation: Eschenbrenner J, Winsel S, Hammer S, Sommer A, Mittelstaedt K, Drosch $M$, Klar $U$, Sachse C, Hannus $M$, Seidel $M$, Weiss B, Merz $C$, Siemeister $G$ and Hoffmann J (2011) Evaluation of activity and combination strategies with the microtubuletargeting drug sagopilone in breast cancer cell lines. Front. Oncol. 1:44. doi: 10.3389/fonc.2011.00044

This article was submitted to Frontiers in Molecular and Cellular Oncology, a specialty of Frontiers in Oncology. Copyright (c) 2011 Eschenbrenner, Winsel, Hammer, Sommer, Mittelstaedt, Drosch, Klar, Sachse, Hannus, Seidel, Weiss, Merz, Siemeister and Hoffmann. This is an open-access article subject to a non-exclusive license between the authors and Frontiers Media SA, which permits use, distribution and reproduction in other forums, provided the original authors and source are credited and other Frontiers conditions are complied with. 